\title{
(i) COOPERATIVE REFURBISHMENT Inclusion of Occupants and other Stakeholders in Sustainable Refurbishment Processes in Multi-Floor Residential Buildings
}

\section{Jürgen Suschek-Berger \& Michael Ornetzeder}

\begin{abstract}
This article deals with the increasing demand for participation in sustainable refurbishment projects. Based on a recently finished study and some conceptual considerations we present a flexible model for involving occupants and other stakeholders in large-volume residential refurbishment projects. The study draws on fifteen interviews with refurbishment experts and three focus group discussions with occupants of recently finished projects. The article shows that in practice it is important to offer approriate opportunities for participation at each phase of the process. Although refurbishment projects in general run through a series of typical phases there is no such thing as a standardized 'ideal' participation process. Rather participation designs for large projects have to be 'tailor-made', taking into account occupants' expectations and abilities, legal requirements, the complexity of projected measures, and finally the often well established 'style of communication' already used by the housing company.
\end{abstract}

Keywords: Participation, Sustainable Refurbishment, Multi-Floor Buildings, Occupants.

\section{INTRODUCTION}

At the beginning of the 21 st century, housing companies are confronted with a kind of paradigm shift. After five decades dominated by house building, refurbishment of the existing stock will become more and more important. Throughout Europe, nearly 170 million people live in multi-floor buildings on some 80,000 housing estates built in the post-war decades of rapid urban expansion (Eriksson \& Dekker, 2000). Given the widely accepted claim for sustainable development, there is huge potential for ecological improvement within the housing sector. At present, about $40 \%$ of energy consumption and emission of greenhouse gases originates from the heating and lighting of buildings (Österreichische Bundesregierung, 1995). There is not only huge potential to cut back energy consumption, but water consumption, household waste management and recycling materials also. Recent research on life cycles of buildings shows that refurbishment in many cases is the more sustainable option compared to replacement by new construction (Klunder, 2005).

However, sustainable refurbishment projects should not only consider ecological and energy related aspects, but also take occupants and other stakeholders into account and try to negotiate mutual interests (ISOE, 2001). This is possible only if stakeholders participate in the planning and process of refurbishment.

This article is based on a finished project (Suschek-Berger \& Ornetzeder, 2006), which was carried out within the national research programme, 'Building of Tomorrow,' initiated and sponsored by the Austrian Federal Ministry of Transport, Innovation and Technology. The aim of the project was to investigate practical experiences of housing companies with occupant participation on the one hand and to learn more about needs of occupants with refurbishment processes in multifloor buildings on the other hand. Selected results have been published in an advisory brochure (Suschek-Berger \& Ornetzeder, 2007).

Empirically, the article is based on three explored refurbishment projects, fifteen interviews with architects, representatives from housing companies and public administrations, three focus groups with occupants in buildings with recently finished refurbishment activities and a concluding workshop with refurbishment practitioners. Theoretically, it builds on the relevant literature on user participation. 


\section{SUSTAINABLE REFURBISHMENT AND PARTICIPATION}

Normative concepts for sustainable refurbishments usually claim to consider a wide range of social, cultural, environmental and economic criteria (ISOE, 2001; for an overview see Mickaityte et al., 2008). According to those concepts, refurbishment projects should be seen as opportunity not only to make necessary repairs, increase comfort or improve the energy standard of the building, but also to consider issues like health, education and public awareness, social safety, land use, noise problems, cost-efficiency, cultural heritage or the wider surroundings of the building. As social aspects play an important role in sustainability concepts in general, participation of occupants and other stakeholders could be seen as an integrated part of sustainable refurbishments projects.

'Participation' is a broad-spectrum term covering a diversity of engagements from information to full mutual equality (Mitcham, 1999). In the field of refurbishment of large volume residential buildings, participation means that occupants have the opportunity to be involved in the whole process irregardless of the extent to which this involvement is put into practice, and whether or not occupants make use of this opportunity. In any case, we could assume that there is one central social actor (e.g. housing association) who is responsible for the refurbishment project. This central actor has also to decide in which phase of the process occupants have to be involved, and to which extent (we will discuss this point in more detail in section 4).

From a more general perspective, Bischoff and colleagues (1995) have emphasised three main arguments for participation in planning processes: legitimation, efficiency and identification. Through a broad process of opinion forming, it is argued, the interests of citizens are taken into consideration and important decisions are democratically authorised (legitimation). The integration of laypeople could also lead to well-informed planning. People are experts of their everyday lives and such knowledge is of high value. It helps to avoid changes afterwards, objections or new planning (efficiency). If citizens are informed and integrated early on, it is more likely that the people concerned will accept and identify with the results (identification).

While democratic arguments stress the rights of those who are effected to have a say the local knowledge of users is at the centre of interest when efficiency is to be achieved. In order to gain as much information as needed, a broad spectrum of viewpoints should be represented in participation processes (Sclove, 1995). Lay knowledge and experience of occupants are indeed of very high value to the management of housing companies. Residents are familiar with problems in their settlement and their own flat so they know the most important areas for the refurbishment process. By using this local knowledge, housing companies are able to spare expensive investigations and planning to a certain degree.

As sustainable refurbishment projects typically are large and broad - covering as much as possible aspects and interdependencies - participation of occupants have to be seen as an integrated part of them. However, involvement of occupants does not lead automatically to the above-described outcomes. To which extent participation will show positive results depends strongly on how the communication process is organised during the whole refurbishment process. Before we will discuss this question in more detail, relevant social players in refurbishment projects and the most important phases of a refurbishment process will be presented in the next section.

\section{THE CURRENT PARTICIPATION PRACTICE IN REFURBISHMENT PROJECTS IN AUSTRIA}

In Austria, a large share of multi-floor buildings is owned by not-for-profit housing associations. These associations call on many years of experience regarding refurbishment projects. In the last 15 years, the requirements for refurbishment projects have increased significantly. While in the past it was standard to re-establish more or less the original condition of the building, current projects go far beyond this practice. Currently significant improvements, particularly with regard to energy saving measures (thermal insulation, new windows, efficient heating systems, solar heaters, etc.), are now state-of-the-art. However, projects aiming at comprehensive sustainable refurbishments are still rare.

As we saw in our interviews on ambitious projects, a large number of stakeholders are involved in refurbishment projects in the field of 
multi-floor buildings. The most important stakeholders are outlined in the following.

\section{The residential housing association}

As the owner of the building, the housing association is the central social player. The association is responsible for the whole refurbishment project, which includes the communication to all partners as well as the organisation of the participation process. Internally, the most closely involved departments are the 'building management' and the 'technical department'. In most cases, the building management is the main organiser of the refurbishment process. The technical department is responsible for planning, invitation of tenders and execution of construction work (sometimes specific steps in the procedure of technical processing are contracted out to external partners, e.g. architects).

\section{Occupants}

Owners of flats or tenants are effected by refurbishments in any case. To initiate and perform a process of participation, occupants must be willing to take part. At least a certain number of residents are usually interested in selected questions. The offers of the building management to participate have to be mutually agreed upon according to the residents' needs and information. It is often difficult to create space and time for all who are potentially interested in order for each to have a chance to participate. On the contrary, occupants should also have the 'right' to exclude oneself from participating in the process.

\section{Construction companies}

The building construction companies play an important role in the process because the beginning of a construction phase is certainly not the end of participation. They have to handle complaints, noise and dirt and safety issues. The companies have to ensure the quality of living during the long lasting construction phase. Professional contact with residents during the construction works, responding flexibly to evolving wishes and needs and conducting professional construction work in cooperation with occupants is an important part of the refurbishment process and must be considered as part of the participation process.

\section{Neighbourhood}

The community's surrounding is also important in the case of a refurbishment process. It is helpful to minimize inconveniences to the neighbourhood and inform neighbours about the planned process. This can be very important in terms of the neighbourhood's satisfaction with the refurbishment process.

\section{Funding agencies or arbitration-boards}

These institutions are also directly involved in the process because, for example, they are charged with forms of inspection in calls for tenders. They are also indirectly involved because they can influence the arrangement of the refurbishment processes by general guidelines. In some regions of Austria, if someone applies for a specific form of ecological support, the degree to which residents should be included is estimated.

Typically, refurbishment projects run through a series of sequential phases. Some of the above mention stakeholders are involved during the whole process, some others only partly or at a particular stage. In the following we will give a short overview of these typical phases.

In the beginning, the housing association comes to a decision as to which object in the owned stock should be retrofitted. When the decision has been made, the next step is a stock-check for clarifying technical details, followed by a rough planning of the refurbishment process. In this phase, a meeting with occupants is usually held, where the concept and costs of refurbishment are presented. If the residents agree to the concept, detailed planning is made as well as a call for tenders in finding building enterprises who can do the construction work. The best bidder is selected from the tenders. If the residents do not agree with the refurbishment costs the project has to be handled at the circuit court, which decides on a reasonable price for the residents. When this has been completed, the construction phase can begin. When the planned and concerted refurbishment work is finished, the project ends with a revisal of costs.

Concerning the question of ecological and energy refurbishment, we learned that the residential housing companies try to use approved strategies for information for and communication with occupants. On the one hand, they want to avoid the residents' discussions or objections, which could compromise the whole process of refurbishment, and on the other hand they often deny the residents' specialised knowledge, which may be very useful 
and helpful for the planning.

Based in these findings and a literature review we have developed a model that offers possibilities for participation in all phases of the refurbishment.

\section{FLEXIBLE MODEL OF PARTICIPATION}

Participation can take place on different levels and with varying degrees of involvement. Based on Beckmann and Keck (1999) and Wilcox (1994), we can distinguish four levels: information, communication, co-design and co-decision. Depending on the intensity of the occupants' involvement, it can start on any of these levels. These four levels cannot be distinguished selectively and do overlap, but with regard to the discussion on advantages and disadvantages of particular participation methods this classification is of central importance.

The flexible model of participation does not represent an 'ideal' participation process. It is rather a question of taking and using it as a 'tool-kit'. Elements and methods towards a suitable process for all phases of refurbishment and all levels of participation can be taken out, combined and used in order to inform or involve occupants. Based on the flexible model it should be possible to compose a 'tailor-made' process for each project. It is important that the selected elements and methods are in accordance with the occupants, the aims of the refurbishment and the 'style of communication' already used by the company.

In the following we discuss a few examples from the flexible model of participation. The model includes suggestions to design the participation process adapted to the different phases of a refurbishment project. Typical phases not only could represent widely spaced intervals but also request for quite different forms of participation.

\section{Initial decision}

In owner-occupied projects it is mandatory to include all occupants in the initial decision-making process (level of co-design). Whereas in projects with rented accommodations participation in this phase may focus to the levels of information and communication. Written information, surveys and excursions to previously retrofitted buildings or developments can be offered in this phase. Occupants should have the opportunity to see examples of successfully refurbished projects and to discuss whether they would like to have their own building retrofitted in a similar way. Small work groups and round tables can be installed to discuss the first steps of the refurbishment process and the potential costs.

\section{Stock check}

In this phase, occupants can be included in the form of building or development inspections. Because occupants know their own residential environment best, they can be invited to evaluate and assess it, as well as to make suggestions for improvement. We did such an inspection in cooperation with a housing association in our project, which brought a number of valuable suggestions for the forthcoming refurbishment process. As there is nothing to decide most methods appropriate for involving occupants in this phase aim at communication or co-design.

\section{Rough planning}

In this phase, participation should be offered on all levels using a mix of different methods. Here, the whole range of possible aspects of sustainability from necessary repairs and ecological improvements to issues like health, social safety or the wider neighbourhood of the building - could and certainly should be addressed for the first time. It is important to provide sufficient information material and to run a two-way communication process during the whole planning. And at some certain points there is also a need for methods to make some important decisions including all or a majority of occupants. Appropriate methods include meetings for all residents and written questionnaires. Important information should be given in advance using oral presentations. Experts are needed to inform occupants about possible ecological options (e.g. selection of ecological construction materials, new heating systems, etc.) in a balanced and comprehensive way. Working groups focusing on specific issues can be organised for a smaller number of interested occupants. In this phase it may also be adequate to invite a broader range of participants, including not only technical experts and occupants but also representatives of the neighbourhood.

\section{Detailed planning and call for tenders}

Detailed plans are worked out on the draft agreed in the previous phase. Although detailed planning 
primarily is done by architects and energy technology experts, methods for communication and forms of co-designs would be possible. A proven but still rarely used method is the occupants' advisory board. This board - made up of a smaller number of named or elected occupants - supports the housing association with the views and meanings of and serves as information agent for occupants. Moreover, members of the board could be consulted when the call for tenders is evaluated and construction companies have to be selected.

\section{Decision}

The decision to commission construction companies is a crucial step in the whole process. In Austria it is mandatory to legitimate this decision with a voting procedure (simple majority of occupants). It is common practice that housing associations inform occupants about the results of the call for tenders including total construction costs in a meeting. The voting is done directly thereafter using written questionnaires. In Austria occupants have the right to submit a written objection if the estimated total cost for the refurbishment works exceed a certain limit (which could cause serious delays). Therefore a comprehensive communication and information policy is of crucial importance in this phase.

\section{Construction phase}

With the beginning of the construction works the context for organising a participation process changes again. A new partner, the construction company has to be integrated. Moreover it could be necessary to intensify the communication with the neighbourhood. Similar to the detailed planning phase an occupants' building committee could be installed, which accompanies and controls the construction work. A permanent on-site presence of the housing company is another option. It can be guaranteed by establishing a site-office, with regular consultation hours.

\section{Reflection}

After the construction works are finished occupants should have the opportunity to check accounts. Also, there should be room for reflection (What was done well in the process? What could have been done better?). As a method to get qualitative feedback a number of focus groups with selected occupants can be applied. This was done with one of our housing association partners to get a deeper feedback regarding the finished refurbishment process, and to get input and proposals for improvements for further activities of the housing association.

As we saw in our project, Austrian residential building associations are interested in tools and possibilities of participation as presented in the flexible model. In rare cases some of the presented methods are used already, such as excursions, working in close connection with elected occupants, small working groups and evaluation of the existing stock together with occupants, the installation of an occupants' advisory board, consultation hours and an office on-site during the construction phase or reflection on the refurbishment process with the involved occupants. However, in a typical refurbishment project only a few methods are used in a standardised way.

\section{CONCLUSION}

In this article, we have argued that sustainable refurbishment of buildings and participation of occupants is becoming more and more important. An early and systematic involvement of occupants could help in avoiding problems concerning the lack of support for extensive refurbishments currently encountered by housing companies.

Main participants in the refurbishment process are the residential building association, occupants, the social environment, construction companies and support institutions. They play an important role in a refurbishment process which includes a number of distinct phases. It is not necessary to involve occupants in all phases of a refurbishment process to the same extent, but it is important to offer appropriate methods of participation in all of these phases. We have shown that it is important to consider methods on four levels of participation (information, communication, co-design and co-decision). Levels and methods should be selected in accordance with the occupants, the requirements of the building, the components of the refurbishment and the 'style of communication' used by the housing company.

In the second part of the article, we have presented a flexible model of participation covering all phases of a refurbishment process and all levels of participation. The basic assumption was that housing companies have a kind of well-established 'tra- 
dition' of how to communicate with occupants. If more participation is needed in the future - e.g. because refurbishments will be larger and more comprehensive due to their sustainable character it is important to build on these well-established communication practices.

\section{REFERENCES}

BECKMANN J., KECK G. 1999, Beteiligungsverfahren in Theorie und Anwendung. Akademie für Technikfolgenabschätzung in Baden-Württemberg, Stuttgart.

BISCHOFF A., SELLE K., SINNING H. 1995, Informieren Beteiligen - Kooperieren. Kommunikation in Planungsprozessen. Eine Übersicht. Verfahren, Methoden und Techniken. Dortmunder Verlag für Bau- und Planungsliteratur, Dortmund.

ERIKSSON T., DEKKER K. 2000, The big buildings set the example. In RDT Info. Magazine for European Research. Brussels: European Communities, 27th September.

ISOE (Institut für Sozialökologische Forschung) 2001, Nachhaltiges Sanieren im Bestand. Leiffaden für die Wohnungswirtschaft. Berlin, Darmstadt, Frankfurt/M., Freiburg.

KLUNDER G. 2005, Sustainable solutions for Dutch housing: reducing the environmental impacts of new and existing houses. Delft.

MICKAITYT A., ZAVADSKAS EK., KAKLAUSKAS A., TUP?NAIT? L. 2008, The Concept Model of Sustainable Buildings Refurbishment. In International journal of strategic property management. Vilnius: Technika, Vol. 12, No. 1, pp. 53-68.

MITCHAM C. 1999, Why the public should participate in technical decision making. In SCHOMBERG, R. (ed.): Democratising Technology. The Netherlands: International Centre for Human and Public Affairs.

ÖSTERREICHISCHE BUNDESREGIERUNG (ed.) 1995, Nationaler Umwelt Plan. Verlag Styria, Graz and Wien.

SCLOVE R. 1995, Democracy and Technology. New York and London.

SUSCHEK-BERGER J., ORNETZEDER M. 2006, Kooperative Sanierung. Modelle zur Einbeziehung von Bewohner und Bewohnerinnen bei nachhaltigen Gebäudesanierungen. Schriftenreihe des BMVIT, 54, Wien.

WILCOX D. 1994, The Guide to Effective Participation. Delta Press, Brighton.

\section{Authors' Addresses}

Jürgen Suschek-Berger

Interuniversity Research Center für Technology, Work and Culture (IFZ), Graz, Austria suschek@ifz.tugraz.at

Michael Ornetzeder

Austrian Academy of Sciences (ÖAW), Institute of Technology Assessment (ITA), Wien, Austria ornetz@oeaw.ac.at 